\title{
SEBARAN PASIEN SAAT PANDEMI COVID-19 DI JAWA BARAT MENGGUNAKAN METODE ORIGIN DESTINATION
}

\author{
Eduard Sondakh'), Saptono Kusdanu Waskito ${ }^{2)}$, Sari Armiati ${ }^{3)}$ \\ 1)D3 Logistik Bisnis, Politeknik Pos Indonesia \\ email: eduardsondakh@poltekpos.ac.id \\ 2)D4 Logistik Bisnis, Politeknik Pos Indonesia \\ email: saptonokusdanu@poltekpos.ac.id \\ 3)D3 Manajemen Informatika, Politeknik Pos Indonesia \\ email: sariarmiati@poltekpos.ac.id
}

\begin{abstract}
Abstrak
Wabah COVID-19, diumumkan secara resmi ada di Indonesia di awal bulan Maret 2020. Sejak saat itu pemerintah pusat melalui Badan Nasional Penanggulangan Bencana (BNPB) sebagai Gugus Tugas Percepatan Penanganan COVID-19 memberikan informasi terkini secara periodik. BNPB juga bekerja sama dengan pemerintah daerah dan pemerintah kota baik dalam penyaluran informasi maupun dalam penyaluran bantuan alat pelindung diri (APD). Pemerintah Provinsi Jawa Barat Bandung pun telah memiliki pusat informasi dan koordinasi COVID-19 melalui pikobar.jabarprov.go.id. Namun demikian muncul permasalahan, beberapa rumah sakit rujukan yang terus ditambah sejalan bertambahnya pasien Covid19 baik di kota maupun kabupaten di Jawa Barat, belum menunjukan apakah kapasitas tersebut memadai sesuai jumlah pasien yang dirujuk atau tidak. Untuk itu dalam penelitian ini dibuat analisis sebaran pasien Covid19 menggunakan metode Origin Destination menggunakan data pasien di bulan Agustus 2020. Tahap kegiatan penelitian yang dilakukan melalui 3 tahapan yaitu survey pencarian data rumah sakit rujukan beserta jumlah kapasitasnya, data pasien positif yang harus dirawat di Jawa Barat dan pemetaan matrik Origin Destination (OD). Kegunaan hasil dari penelitian ini adalah berupa kajian pemenuhan kebutuhan layanan kesehatan terhadap pasien Covid19 di Jawa Barat dan dapat dijadikan dasar pengembangan perancangan sistem pelayanan rumah sakit rujukan terhadap pasien Covid19.
\end{abstract}

Kata Kunci: origin destination, Covid19, sebaran

\section{PENDAHULUAN}

Presiden Jokowi mengumumkan kasus WNI positif virus corona pertama kali pada 2 Maret 2020 [1]. Sejak saat itu, jumlah kasus pasien terkonfirmasi positif virus corona di Indonesia telah mencapai 2.738 pasien dengan angka kematian mencapai 221 jiwa per 7 April 2020 [2]. Jumlah kasus pasien terkonfirmasi positif virus corona di provinsi Jawa Barat mencapai 343 dengan angka kematian sebanyak 29 jiwa per 7 April 2020 [2]. Sementara jumlah kasus pasien terkonfirmasi positif virus corona di Bandung mencapai 61 orang dengan angka kematian sebanyak 18 orang per 7 April 2020 [2].

Melihat terus meningkatnya jumlah penderita virus corona di Indonesia, pemerintah melakukan berbagai upaya untuk mencegah dan memutus penyebaran virus corona dengan melakukan himbauan agar masyarakat menjaga jarak fisik (physical distancing), agar masyarakat melakukan kerja dari rumah (work from home), belajar dari rumah, hingga beribadah di rumah. Namun, upaya-upaya pemerintah tersebut harus didukung oleh masyarakat. Masyarakat harus juga berperan aktif dalam membantu pemerintah mencegah dan memutus penyebaran virus corona ini. Oleh karena itu pemerintah terus berupaya untuk menguatkan kesadaran dan kemampuan kesehatan masyarakat secara mandiri untuk hidup sehat melalui program Gerakan Masyarakat Hidup Sehat (GERMAS). GERMAS berfokus pada dorongan masyarakat untuk berprilaku hidup sehat yang dipercaya bisa mencegah penyebaran corona. GERMAS mendorong masyarakat untuk makan dengan gizi yang seimbang, rajin olahraga dan istirahat cukup, cuci 
tangan pakai sabun, jaga kebersihan lingkungan, tidak merokok, gunakan masker bila batuk atau tutup mulut dengan lengan atas bagian dalam, minum air mineral 8 gelas/ hari, makan makanan yang dimasak dan jangan makan daging dari hewan yang berpotensi menularkan, bila demam dan sesak nafas segera ke fasilitas kesehatan, dan jangan lupa berdoa [3].

Di sisi lain pemerintah daerah bekerja sama dengan pemerintah pusat dan pemerintahan kota untuk berkoordinasi dalam penyebaran informasi dan penyaluran bantuan. Masyarakat pun selain disiplin hidup sehat, semakin banyak yang terlibat gotong royong melakukan penggalangan dana maupun bantuan bagi garda terdepan kesehatan terkait alat perlindungan diri (APD) maupun bantuan untuk masyarakat kurang mampu yang tidak dapat bekerja secara normal akibat pembatasan sosial berskala besar. APD digunakan oleh petugas kesehatan pada saat rapid test (dan pemeriksaan lain), pengelolaan pasien di rumah sakit dan pengeloaan karantina dan isolasi. Pada awalnya penelitian ini berfokus pada analisis supply APD di rumah sakit rujukan Kota Bandung berdasarkan pasien rujukan Covid 19, agar bantuan dari pemerintah maupun dari masyarakat dapat dipantau dan distribusinya merata ke seluruh rumah sakit rujukan, khususnya di kota Bandung. Dikarenakan terdapat kendala tidak ada publikasi maupun transparansi data sumber-sumber bantuan (supplier) maupun rumah sakit yang membutuhkan (demand) maka penelitian ini mengalami perubahan judul sesuai yang telah diajukan sebelum proses monitoring dan evaluasi penelitian internal dilaksanakan.

Penelitian akan berfokus pada analisis sebaran pasien positif Covid19 yang di rumah sakit rujukan di kota dan kabupaten Provinsi Jawa Barat. Hal ini didasarkan data pasien dari Bulan Agustus 2020 dan data kapasitas rumah sakit rujukan tiap kota dan kabupaten di Jawa Barat. Khususnya, penelitian ini berupaya untuk menjawab apakah distribusi pasien positif Covid19 ke rumah sakit rujukan sudah optimal di bulan Agustus 2020. Tujuan penelitian ini adalah untuk mengetahui apakah distribusi pasien positif Covid19 tersebut sudah optimal.

\section{METODE PENELITIAN}

Langkah-langkah dalam penelitian akan mengikuti metode penelitian pada Gambar 1.

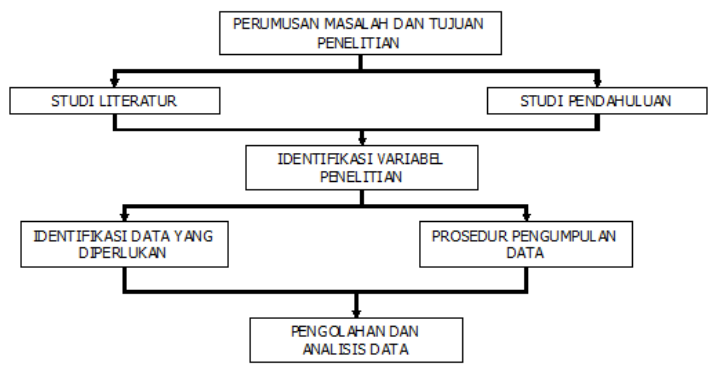

Gambar 1. Metode Penelitian

Sumber: olahan Peneliti

1) Perumusan Masalah dan Tujuan Penelitian

Penelitian diawali dengan mengumpulkan data pasien yang harus dirujuk ke rumah sakit dan jumlah kapasitas rumah sakit rujukan di tiap kota dan kabupaten di Jawa Barat yang kemudian dibuat matrik origin-destination untuk mendapatkan model distribusi yang sesuai.

2) Studi Literatur

Studi literatur dilakukan untuk mendapatkan teori atau konsep, model maupun komponen yang relevan dengan masalah penelitian beserta metodologinya, termasuk best pratices yang telah dilakukan oleh industri tipikal. Teori, konsep, model yang dipelajari antara lain konsep-konsep tentang supply chain management, distribusi dan model transportasi. Berdasarkan teori, konsep, dan praktek yang dipelajari tersebut, disertai dengan studi pendahuluan yang dilakukan maka dapat ditarik kesimpulan teoritis untuk menentukan variabel-variabel penelitian.

3) Studi Pendahuluan

Tahap ini dilakukan untuk mendapatkan informasi tentang komponen-komponen yang perlu dirumuskan dalam membuat matrik origin-destination berdasarkan data supply dan demand. Berdasarkan studi pendahuluan dan studi literatur yang dilakukan maka dapat diperoleh gambaran variabel yang diperlukan dalam penelitian ini.

4) Identifikasi Variabel Penelitian

Berdasar teori dan konsep yang relevan dengan masalah yang diteliti dan dari studi pendahuluan yang dilakukan, maka bisa diidentifikasi variabel yang diperlukan dalam penelitian ini. Identifikasi variabel penelitian ini mengacu pada komponen-komponen perhitungan matrik Origin Destination.

5) Identifikasi Data yang Diperlukan Tahap ini dilakukan untuk menentukan data yang diperlukan dalam penelitian. Sesuai dengan tujuan dan kerangka penelitian yang telah dibangun, data-data yang diperlukan terdiri dari data supply dan data demand berupa pasien dan kapasitas rumah sakit rujukan di Provinsi Jawa Barat.

6) Prosedur Pengumpulan Data 
Ada beberapa cara yang sering dilakukan untuk pengumpulan data, antara lain pengamatan langsung (observasi), data sekunder dari sumber lain, atau kombinasinya. Karena data yang diperlukan adalah data primer dan sekunder, maka penelitian ini menggunakan kombinasi dari beberapa cara tersebut.

\section{HASIL DAN PEMBAHASAN}

Klasifikasi pasien yang terpapar Covid19 pada masa pandemik ini menurut definisi operasional dalam [1] adalah pertama, Orang Tanpa Gejala (OTG) yaitu orang yang tidak bergejala dan memiliki risiko tertular dari orang positif COVID-19 dan telah kontak erat dengan kasus positif COVID-19. Kedua adalah Orang Dalam Pemantauan (ODP) yaitu orang yang mengalami demam $<=38$ derajat atau riwayat demam; atau gejala gangguan sistem pernapasan seperti pilek/sakit tenggorokan/batuk. Ketiga adalah Pasien Dalam Pengawasan (PDP) yaitu orang dengan Infeksi Saluran Pernapasan Akut (ISPA) yaitu demam (=38 derajat) atau riwayat demam; disertai salah satu gejala/tanda penyakit pernapasan. Keempat adalah pasien terkonfirmasi yaitu pasien yang terinfeksi COVID-19 dengan hasil pemeriksaan tes positif melalui pemeriksaan PCR.

Menurut Direktur Jenderal Pelayanan Kesehatan Kementrian Kesehatan Republik Indonesia dalam [2] pada pandemi COVID-19 sangat penting khususnya Puskesmas dalam melakukan prevensi, deteksi dan respon di dalam pencegahan dan pengendalian COVID-19, puskesmas harus mampu mengelola, memanfaatkan sumber daya yang dimilikinya secara efektif dan efisien dalam memutus mata rantai penularan, baik di level individu, keluarga dan masyarakat. Adapun proses bisnis perujukan seorang pasien yang dinyatakan harus dirawat menurut [2] digambarkan pada Gambar 2.

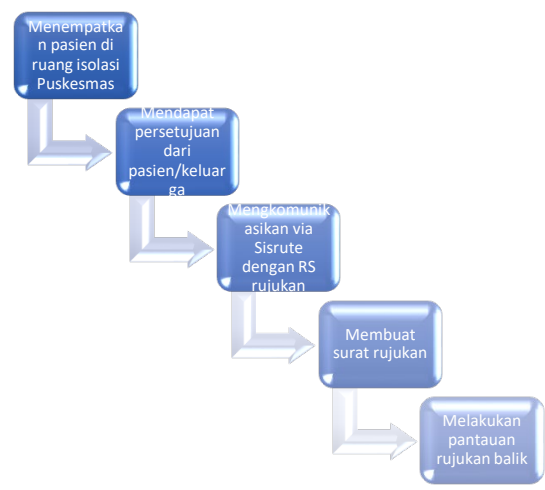

Gambar 2. Proses bisnis perujukan pasien
Sumber: Petunjuk Teknis Pelayanan Puskesmas Pada Masa Pandemi Covid-19 (2020)

Standar pelayanan perujukan pasien :

a. Puskesmas menempatkan pasien yang akan dirujuk pada ruang isolasi tersendiri yang terpisah.

b. Mendapat persetujuan dari pasien dan/atau keluarganya.

c. Melakukan pertolongan pertama atau stabilisasi pra rujukan.

d. Melakukan komunikasi dengan penerima rujukan melalui pemanfaatan aplikasi SISRUTE (https://sisrute.kemkes.go.id/) dan memastikan bahwa penerima rujukan dapat menerima (tersedia sarana dan prasarana serta kompetensi dan tersedia tenaga kesehatan). Rujukan Suspek PDP melalui Sisrute mengacu pada user manual sebagaimana lampiran buku Juknis ini.

e. Membuat surat pengantar rujukan dan resume klinis rangkap dua.

f. Transportasi untuk rujukan sesuai dengan kondisi pasien dan ketersediaan sarana transportasi.

g. Pasien yang memerlukan asuhan medis terus menerus didampingi oleh tenaga Kesehatan yang kompeten dan membawa formulir monitoring khusus untuk kasus COVID-19 sesuai dengan Pedoman.

h. Pemantauan rujukan balik.

Data pasien terkonfirmasi Covid19 di Jawa Barat menurut [3], yang dipublikasikan data tersebut ada pada rentang waktu dimulai dari 1 Agustus 2020 (data disajikan per hari per kota/kabupaten) sebagaimana terlampir. Data yang dicapture dalam penelitian ini adalah akumulasi dari pasien Covid-19 terkonfirmasi dalam 1 bulan yaitu bulan Agustus 2020 yang telah diolah. Data tersebut terdapat pada Gambar 3.

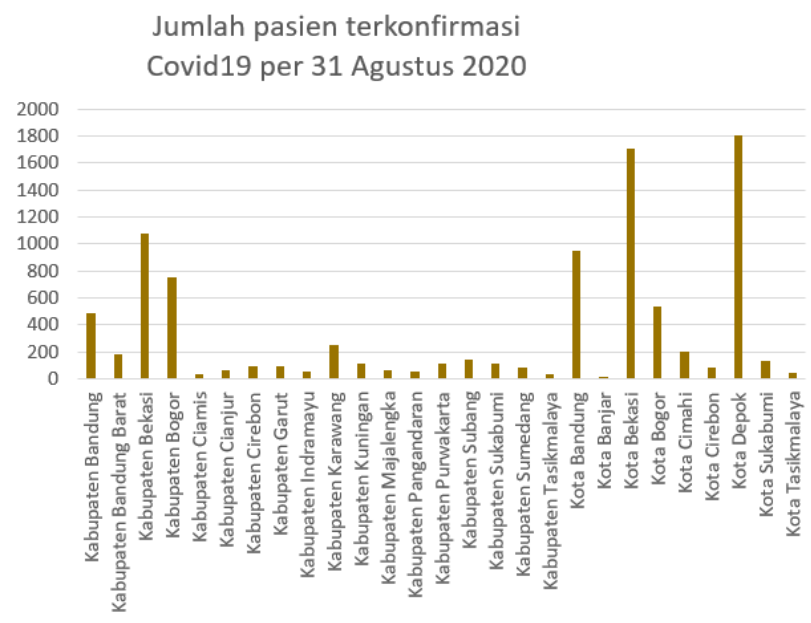

Gambar 3. Grafik jumlah pasien terkonfirmasi Sumber: Data Kasus Covid-19 Jawa Barat (2020). https://pikobar.jabarprov.go.id/table-case 
Berdasarkan data kasus sampai periode 30 Agustus 2020 pada Gambar 3, terdapat empat daerah tersebut yakni Kota Bekasi, Kota Bogor, Kota Depok, dan Kabupaten Bekasi. Dengan demikian, wilayah Bodebek merupakan Zona Merah kecuali Kabupaten Bogor. Selain itu terdapat 10 kabupaten/kota berstatus zona oranye, yakni Kabupaten Bogor, Kabupaten Bandung, Kabupaten Majalengka, Kabupaten Purwakarta, Kabupaten Karawang, Kabupaten Bandung Barat, Kota Bandung, Kota Cirebon, Kota Cimahi, dan Kota Tasikmalaya.

Sementara 13 kabupaten/kota lainnya berada di Zona Kuning, yaitu Kabupaten Sukabumi, Kabupaten Cianjur, Kabupaten Garut, Kabupaten Tasikmalaya, Kabupaten Ciamis, Kabupaten Kuningan, Kabupaten Cirebon, Kabupaten Sumedang, Kabupaten Indramayu, Kabupaten Subang, Kabupaten Pangandaran, Kota Sukabumi, dan Kota Banjar. Berdasarkan data rumah sakit dan pasien Covid19 terkonfirmasi maka pola distribusi dapat diperoleh dengan mempergunakan Matriks Origin Destination pada Tabel 1 sebagai contoh hasil pengolahan. Hal ini dilakukan agar distribusi dapat dilakukan secara optimal dan pola distribusi ini dapat dipergunakan sebagai alat monitoring bahwa sebaran pasien masih dapat ditangani oleh rumah sakit rujukan di Provinsi Jawa Barat. Perhitungan pola optimalisasi distribusi ini mempergunakan data Bulan Agustus tahun 2020 pada Gambar 3.

Tabel 1. Matriks Origin Destination Distribusi Pasien ke Rumah Sakit 47-66 di Jawa Barat

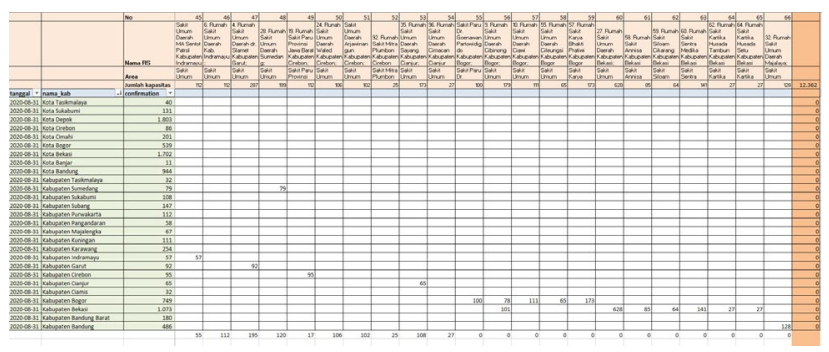

Sumber: olahan Peneliti berdasarkan Data Kasus Covid-19 Jawa Barat (2020).

Dari hasil perhitungan supply kapasitas rumah sakit dengan demand berupa pasien Covid19, dapat dirancang sebuah pengembangan sistem perangkat lunak yang dibuat guna memberikan kemudahan pihak pembangun sistem (developer aplikasi) dalam mengembangkan produk penelitian berbasis web, yang dapat memberikan kemudahan bagi pihak rumah sakit dan pasien untuk mendapat informasi yang berkaitan dengan pengelolaan demand dan supply tempat perawatan pasien Covid19. Mulai dari informasi mengenai rumah sakit rujukan, jumlah kapasitas ruang rawat untuk pasien Covid19, jumlah pasien Covid19 yang memerlukan perawatan selain isolasi mandiri serta distribusi pemenuhan demand menggunakan matrik Origin Destination Matrix. Metode ini digunakan untuk mengukur pola sebaran pergerakan, sebagaimana dilakukan dalam [4] dan [5].

Pengguna sistem yang akan menjadi entitas pengguna pada rancangan ini staf yang berada pada rumah sakit rujukan dan staf pada Puskesmas. Staf rumah sakit berfungsi sebagai administrator aplikasi yang mengelola data rumah sakit, kelola data kapasitas rumah sakit terkait, data pasien Covid19, sedangkan staf tiap Puskesmas menginputkan pasien rujukan, melihat dan mencetak laporan tiap periode. Fungsi dari sistem ini adalah untuk mengelola data supply dan demand berupa kapasitas tempat rawat dan permintaan jumlah rujukan pasien Covid19 serta pemenuhannya menggunakan matrik Origin Destination. Data- data tersebut dikelola dan akan memperoleh informasi berupa laporan pemenuhan perawatan pasien Covid-19 per rumah sakit.

Perangkat lunak yang dirancang memiliki fitur-fitur sebagai berikut :

1. Melakukan validasi (login) untuk staf rumah sakit dan staf puskesmas. Fungsi ini dimaksudkan agar pihak pihak yang tidak berkepentingan tidak dapat mengakses sistem informasi (keamanan). Dan pihakpihak yang dapat mengakses juga dibatasi haknya.

2. Kelola data pengguna

3. Kelola data rumah sakit dan Puskesmas

4. Kelola data kapasitas bed/kamar

5. Kelola data pasien Covid19, rujukan dan statusnya

6. Hitung dan tampil matrik Origin Destination

Berikut ini dijelaskan semua kebutuhan perangkat lunak hingga pada tingkat rinci yang memungkinkan pengembangan untuk merancang sistem, untuk memenuhi kebutuhan tersebut. Seperti diketahui bahwa perangkat lunak yang akan dibangun membutuhkan beberapa aspek agar dapat dibangun. Maka dibawah ini akan dijelaskan tentang kebutuhan perangkat lunak apa saja yang mempengaruhi pembangunan perangkat lunak.

\section{Antarmuka pemakai}

Pemakai akan berinteraksi dengan sistem dengan menggunakan perangkat I/O sebagai berikut:

- Keyboard, digunakan oleh pengguna untuk memasukan perintah kedalam aplikasi.

- Mouse, digunakan oleh pengguna untuk melakukan perintah terhadap aplikasi secara modus GUI (Graphical Pengguna Interface).

- Monitor, digunakan oleh pengguna untuk melihat aplikasi.

- Printer, digunakan oleh pengguna untuk mencetak laporan.

\section{Antarmuka perangkat keras}


Antarmuka perangkat keras menggunakan modem atau wifi karena system berbasis web sehingga diperlukan jaringan internet.

\section{Antarmuka perangkat lunak}

Antarmuka yang digunakan adalah web browser (GUI) untuk mengakses server yang menyimpan dan memperlihatkan informasi sesuai query.

\section{Antarmuka komunikasi}

Antarmuka komunikasi yang digunakan adalah koneksi berbasisi protokol TCP/IP (internet). Protokol ini digunakan untuk komunikasi permintaan data ke server basis data MySql.

\section{Kebutuhan Fungsional}

Berdasarkan kebutuhan dalam mempersiapkan sistem, maka dirancang model sistem sebagai berikut:

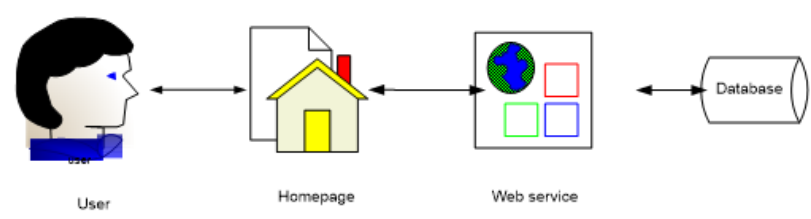

Gambar 4. Model untuk implementasi Sumber: hasil pemikiran Peneliti

Keterangan :

- User: Pengguna dari aplikasi. User untuk aplikasi ini dibagi menjadi dua jenis yaitu staf rumah sakit dan staf Puskesmas.

- Homepage: Aplikasi sistem yang dapat diakses melalui browser berbasis web

- Web service: Domain hosting agar system dapat diakses di internet

Sistem dirancang menggunakan Unified Modelling Language (UML), UML digunakan karena merupakan pemodelan berbasis objek, hal ini diselaraskan dengan penggunaan pemrograman Java pada fase impelementasi.

\section{Use Case Diagram}

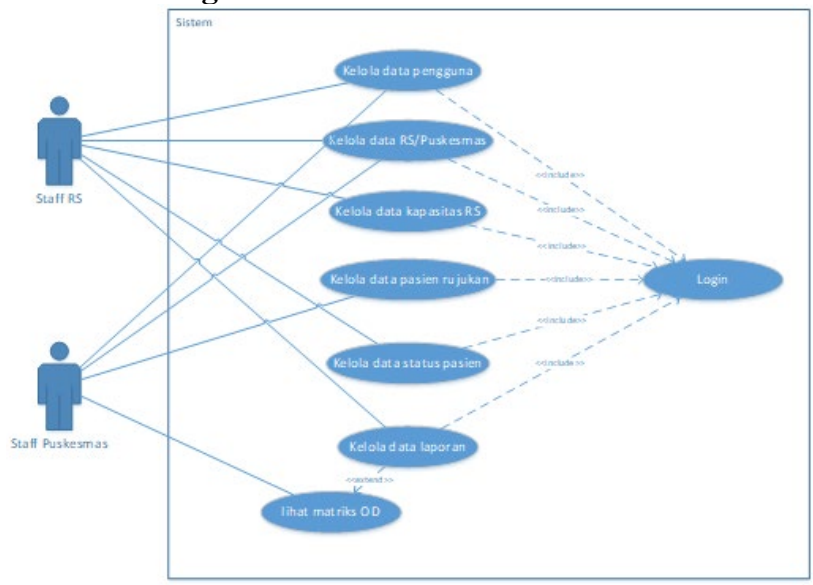

Gambar 5. Use Case System
Sumber: olahan Peneliti

Pada Gambar 5, dirancang use case system, yang terdiri dari dua aktor yakni staf rumah sakit dan staf Puskesmas. Untuk penjelasan tiap use case tersebut terdapat pada Tabel 2.
Tabel 2. Penjelasan Use Case

\begin{tabular}{|l|l|l|}
\hline No & \multicolumn{1}{|c|}{ Use Case } & \multicolumn{1}{c|}{ Deskripsi } \\
\hline 1. & Login & $\begin{array}{l}\text { Rancangan proses untuk fitur validasi login setiap actor } \\
\text { yang akan mengakses system. }\end{array}$ \\
\hline 2. & Kelola data pengguna & $\begin{array}{l}\text { Rancangan proses untuk fitur untuk melihat, menambah, } \\
\text { mengubah dan menghapus data pengguna. }\end{array}$ \\
\hline 3. & $\begin{array}{l}\text { Kelola data rumah } \\
\text { sakit/puskesmas }\end{array}$ & $\begin{array}{l}\text { Rancangan proses untuk fitur untuk melihat, menambah, } \\
\text { mengubah dan menghapus data rumah sakit atau } \\
\text { puskesmas. }\end{array}$ \\
\hline 4. & Kelola data kapasitas & $\begin{array}{l}\text { Rancangan proses untuk fitur untuk melihat, menambah, } \\
\text { mengubah dan menghapus data kapasitas rumah sakit. }\end{array}$ \\
\hline 5. & Kelola data pasien rujukan & $\begin{array}{l}\text { Rancangan proses untuk fitur untuk melihat, menambah, } \\
\text { mengubah dan menghapus data pasien rujukan. }\end{array}$ \\
\hline 6. & Kelola status pasien & $\begin{array}{l}\text { Rancangan proses untuk fitur untuk melihat, menambah, } \\
\text { dan mengubah status pasien rujukan. }\end{array}$ \\
\hline 7. & Kelola laporan & $\begin{array}{l}\text { Rancangan proses untuk fitur untuk melihat dan } \\
\text { mencetak laporan }\end{array}$ \\
\hline 8. & Lihat Matrik OD & $\begin{array}{l}\text { Rancangan proses untuk fitur menampilkan matrik } \\
\text { Origin Destination, yang memperlihatkan hasil } \\
\text { pemenuhan supply terhadap demand. }\end{array}$ \\
\hline
\end{tabular}

Sumber: olahan Peneliti

Setelah dijelaskan dalam use case, dalam penelitian lain dapaat dilakukan pengembangan sistem didekomposisikan secara rinci ke dalam System Sequence Diagram, Domain Model, Sequence Diagram, dan Class Diagram tahap analisis yang mendeskripsikan apa saja yang dapat dilakukan actor ke sistem secara teknis, dan bagaimana sistem dapat menampilkan informasi yang diharapkan melalui pesan-pesan (method) ke setiap object (candidate class).

\section{KESIMPULAN}

Setelah melakukan mengumpulkan data mentah, analisis dan perhitungan matrik data pasien dan rumah sakit rujukan di Jawa Barat disimpulkan bahwa terjadi distribusi yang optimal berdasarkan data pasien Covid19 terkonfirmasi dan rumah sakit rujukan bulan Agustus 2020. Dengan demikian, semua pasien Covid19 terkonfirmasi yang wajib dirawat tertangani oleh kapasitas rumah sakit rujukan pada bulan Agustus 2020. 


\section{REFERENSI}

[1] Gugus Tugas Percepatan Penanganan Covid-19, "Pedoman Penanganan Cepat Medis dan Kesehatan Masyarakat Covid-19 di Indonesia," 23 Maret, pp. 1-38, 2020.

[2] Kementerian Kesehatan Republik Indonesia, Petunjuk Teknis Pelayanan Puskesmas Pada Masa Pandemi Covid-19. 2020.

[3] O. website P. P. J. Barat, "Data Kasus Covid-19 Jawa Barat (Public Version)," 2020. [Online]. Available: https://pikobar.jabarprov.go.id/tablecase.

[4] Widianingrum, W.\&Isa, I. (2017). Model Tarikan Pergerakan dan Pola Sebaran Pergerakan pada Kawasan Industri Agrobisnis Jabung. Fakultas Teknik Universitas Brawijaya

[5] Dragu, V., \& Roman, E. A. (2019). The OriginDestination Matrix Development. MATEC Web of Conferences, 290, 06010. https://doi.org/10.10 $51 /$ matecconf $/ 201929006010$ 